\title{
Differentiated financing of schools in French-speaking Belgium: prospectives for regulating a school quasi-market
}

\author{
Marc Demeuse $^{1}$, Antoine Derobertmasure, Nathanaël Friant ${ }^{2}$ \\ Institute of School Administration, University of Mons, Mons, Belgium
}

(Received 2009; final version received 2009)

\begin{abstract}
The school quasi-market in French-speaking Belgium is characterised by segregation of various types. Efforts to apply measures that encourage greater social mixing have met with stiff resistance and various difficulties. In 2008 and 2009, a significant amount of turbulence was caused by the application of the "social mixing" law influencing the registration procedures for students in secondary education. The purpose of this article is to present some results from a prospective research project that investigated the possibility of modifying the formula for financing schools, the foundation of the quasimarket mechanism. To do this, a generalised formula for allocating funds to schools according to need is proposed on the basis of legislation currently in force in the French Community of Belgium. Then, the solution tested is presented with a financing formula that takes into account indicators of the social composition of the school population. Various scenarios of differentiated financing of schools according to these indicators are presented, through simulations using real data on the effects of these scenarios in terms of gains and losses first for all schools, and then for different contrasting schools thereafter. Finally, the implications of these scenarios are discussed and put into perspective with respect to the different solutions considered since 2005 in Frenchspeaking Belgium.
\end{abstract}

Keywords: Prospective, social mixing, regulation

\section{Introduction}

\subsection{Managing diversity, taking disparities into account}

It is undoubtedly unnecessary to remind the reader that not all educational systems are organised in the same way, particularly in terms of the means by which they take into account the diversity of the students in their schools and the way this diversity is manifested in the various institutions. In order to take this into consideration, it is useful to consider several levels of analysis - from the most macroscopic level to the organisation of individual classes and learning groups - and a large number of variables, such as for example the more or less public nature of education and the

\footnotetext{
1 inas@umons.ac.be

2 This article presents certain results of an interuniversity research project commissioned by the Government of the French Community of Belgium in the framework of priority 9 of the "Contrat pour l'École". The research was carried out by Marc Demeuse, Antoine Derobertmasure, Nathanaël Friant and Nathalie Verdale for the University of Mons-Hainaut; and Christian Monseur, Thomas Herremans and Simon Uyttendaele for the University of Liège.
} 
place of private schools (subsidised or not) in the system, the uniform or situationadapted $^{3}$ means of financing, the existence of monitoring mechanisms (for example through nationwide examinations), and the means of correcting disparities ${ }^{4}$. These examples highlight the variety of principles and means that can intervene to limit gaps in performance between different schools (Demeuse \& Baye, 2007; Mons, 2007).

Certain systems - at least in their rhetoric - are based on a stringent equalisation of funding to allow the merits of each student to shine through: this is the ideal of the Republican school in France. Other systems favour adapted and differentiated funding in order to ensure a true equalisation of results, at least in compulsory education, as is the case in educational systems in Northern Europe. Still other systems, rather rare, historically favour private initiative through great autonomy and sometimes even public financing. This is the case in Belgium. In such a context, where the public authority plays at best a subsidiary role as one of several organisers of education, this authority has very little leverage to encourage a certain social mixing or an equalisation of results other than in the way it allocates public funds to all educational operators, public and private. It is in this very particular and extremely open context that the authors propose to consider the mechanisms of regulating school and social disparities by means of differentiating allocation of school funding.

\footnotetext{
${ }^{3}$ For example, the existence of compensatory policies favouring some populations considered as underprivileged, for instance in the case of the famous "Title I" in the United States (Borman, Stringfield \& Slavin, 2001).

${ }^{4}$ Such as the possibility of closing certain schools that are not considered efficient ("failing schools") or distributing "vouchers" that allow the most underprivileged students to leave these schools and go to schools that are considered more efficient.
} 


\subsection{In the French Community of Belgium: a quasi-market}

It is useful here to describe the context of the French Community of Belgium and the quasi-market nature of its education system. Education in Belgium is based on the constitutional right of "freedom of education" (article 24 of the Constitution of 18 February 1831), granting parents the possibility to choose their child's school. This freedom of choice is combined with public financing of education - including private schools - and a method of calculating the financing of each institution according to the number of students registered. Different authors (Vandenberghe, 1998; Delvaux, Demeuse and Dupriez, 2005) have characterised this context as a school quasi-market.

Following this logic, pupils have not only a "financial" value, because their numbers determine the subsidies awarded to each institution (first-order competition), but also a "pedagogical" value based on their more or less desirable personal traits (second-order competition) (Maroy, 2006). Schoolchildren that conform to school norms will be that much easier for the school to manage. Numerous authors have in addition demonstrated that peers play an important role in a pupil's learning (Slavin, 1990; Duru-Bellat \& Mingat, 1997; Vandenberghe, 1998; Crahay, 2000; Ireson \& Hallam, 2001; Dupriez \& Draelants, 2003; Monseur and Crahay, 2008): while learning, a pupil is influenced by the characteristics of the other pupils in his class or school. In fact, teachers are also influenced by the composition of the group of pupils in their classroom and adapt the demands of the curriculum and the evaluation to these pupils (Thrupp, 1999; Thrupp \& al., 2002; Dumay, 2004).

The school hopes to respond appropriately to parents' choices by providing quality education and in turn cultivate a certain demand from parents. A school that does not satisfy the most demanding parents will see them withdraw their children, taking with them the funds that allow the school to operate and thus reducing the 
resources available. In light of this, it is understandable that schools are not only in competition but also interdependent. This is what Delvaux and Joseph (2003) have called competitive interdependence between institutions: "the distribution of pupils, mainly determined by the free choice of parents but also by the relegation processes that exist between institutions, produces hierarchical positions among schools and these influence the strategies and actions that headmasters develop in their institutions and that are "formally" in their zone of autonomy. Schools located in the same local space are interdependent insofar as the workings of a school depend on its position in the local school hierarchy and indirectly on the workings of the other institutions in this space".

\subsection{A quasi-market and... a marked segregation between schools}

These particularities of the educational system in French-speaking Belgium foster segregation of schools and create several "types" of schools on a continuum from "ghetto" schools to "sanctuary" schools. Different examples of segregation have been observed in numerous studies (Crahay, 2000; Demeuse et al., 2005; Baye et al., 2004; Vandenberghe, 2000; Delvaux and Joseph, 2003; Demeuse and Baye, 2007; 2008), and updated in 2008 (Friant et al., 2008). Not only are there great socio-economic disparities between schools, related to the type of programmes they offer, but also, when we look at the institutions on the extreme ends of this continuum, we see that the situation is worsening: the most privileged institutions dispose of their most underprivileged pupils, whereas the most underprivileged schools cannot keep their most privileged pupils.

Acknowledging this, the Government of the French Community of Belgium set out to encourage social mixing within schools, in particular through the "Contrat 
pour l'Ecole" (2005). To do this, two complementary lines of action were proposed: regulating registration and differentiating financing. In the first case, the motivation is to ensure that all parents receive truly identical treatment (setting up a registration record in all schools, managing enrolment according to common and identical rules avoiding favouritism). In the second case, by balancing the recruitment of more "difficult" schoolchildren with a larger school staff, the legislator aims to compensate for these difficulties by increasing funding and manpower. In this article, we will concentrate on the second type of action.

\subsection{One action to study: differentiated financing}

While actions aimed at greater social mixing by regulating school registration have been implemented (the "registration" law in 2007 and the "social mixing" law in 2008) and greatly criticised, the idea of instating differentiated financing is following another path, initially inspired by a compensatory approach. The "Contrat pour l'École" initiated this project by studying the efficiency and feasibility of directly linking the calculation of the number of teaching hours to the socio-economic background of each pupil in the school (Contrat pour l'école, 2005, p. 46). The interuniversity research project commissioned by the Government to be performed by the universities of Mons-Hainaut and Liège had the goal of setting up new measures to fight school segregation thanks to a modulation of the financing of primary and secondary schools (Demeuse et al., 2007). This article presents some of the results of this research: the development of a general formula for financing institutions and of a simulation tool making it possible to establish different financing scenarios. These scenarios are compared with the differentiated resource allocation solution finally proposed by the Government at the beginning of 2009 . 
In this commissioned research project, the relationships and the nature of the roles established between politics and science are part of the third step in the evolution of educational research described by Aubert-Lotarski et al. (2007): prospective research. In this kind of research, the implication of researchers in the outfitting, even the definition, of policies to come constitutes an important change: abandoning an essentially descriptive or explanatory method, this new approach is geared towards defining solutions or scenarios that have a good chance of meeting objectives in the long term. The first prototype of this kind of research was made in the French Community of Belgium in the context of an interuniversity research project on school districts (Delvaux et al, 2005).

\section{A tool for the commissioned research: the incentive power of financing formulas}

\subsection{What are financing formulas?}

The stake of research is to formalise and test means of equitably allocating resources according to the needs of institutions while encouraging social mixing. The request made to our research team was fulfilled by implementing a general formula for allocating funds according to needs similar to the formulas developed by the International Institute for Educational Planning (UNESCO) and summarised by Ross and Levacic (1999).

As a general rule, financing formulas have four components (Ross \& Levacic, 1999): (1) a basic student allocation (BSA), (2) an increase in the basic student allocation according to the curriculum (CE), (3) additional funds for students with special educational needs (SEN) and (4) additional funds for school sites needs 
$(\mathrm{SSN})^{5}$. For the moment in French-speaking Belgium, these four components are represented in a set of calculations that have been modified and added to with each new political impetus and whose coherence is rather difficult to understand.

Simplifying it as much as possible, the current formula for allocating funds in terms of personnel in mainstream education in French-speaking Belgium can be summarised as follows:

Funding for personnel $=(\mathrm{BSA} * \mathrm{CE})+\mathrm{SEN}+\mathrm{SSN}$

The basic student allocation (BSA) corresponds to the number of teachers per capita, according to the number of students, but these resources are not distributed equally according to the curriculum of the students: for example, technical and vocational schools have a greater workforce than general education (CE). It is useful therefore to take into account a multiplier coefficient associated with the type of studies. Additional funding for students with special educational needs (SEN) exists in the educational system in French-speaking Belgium, through positive discrimination $^{6}$ and in special education. Finally, the specific school sites needs (SSN) are taken into account in the appropriation of operating funds and in the calculation of the staff according to brackets of students, also taking into consideration the size of the institution, with smaller institutions and older public institutions receiving proportionally higher operating funds.

\footnotetext{
${ }^{5}$ The acronyms are based on the English formulation of Ross and Levacic (1999): Basic student allocation (BSA), Curriculum enhancement (CE), Supplementary educational needs (SEN), School sites needs (SSN).

${ }^{6}$ For a description of the positive discrimination policy in French-speaking Belgium, see Friant, N., Demeuse, M., Aubert-Lotarski, A. \& Nicaise, I. (2008). "En Belgique. Deux modes de régulation des effets d'une logique de quasi-marché". In M. Demeuse, D. Frandji, D. Greger, \& J-Y. Rochex (Eds), Les politiques d'éducation prioritaire en Europe: Conceptions, mises en œuvre, débats. Lyon: INRP.
} 
The present research has attempted to build a financing formula that includes a socioeconomic factor and that is both equitable and an incentive for social mixing within institutions. In order to modulate the allocation of funds, the general formula is fed by objective indicators of the situation of institutions. The indicators built represent segregational mechanisms at work in the institutions of the French Community of Belgium. These indicators ${ }^{7}$ can then be introduced into a general financing formula in order to compensate for these mechanisms and to incite schools to take the risk of having a more heterogeneous school population. In this article, we will only consider the case of the weighting of school financing according to the socio-economic status of pupils. Because we are dealing with weighting, the SEN component is no longer additive but multiplicative and the formula is transformed as follows:

Funding for personnel $=(\mathrm{BSA} * \mathrm{CE}) * \mathrm{SEN}+\mathrm{SSN}$

This type of formula fills three main functions - equitable distribution of resources, incentive, regulation of the market ${ }^{8}-$, in such a way that it responds to the political will by modulating the allocation of resources according to the characteristics of the population of each school. The objective of social mixing brings into play the "incentive" function of financing formulas: the formula has the purpose of encouraging (and/or sanctioning, in the "Robin Hood" case that we will refer to later) the strategies of institutions with respect to the objectives defined by educational policy.

\footnotetext{
${ }^{7}$ For more information about the construction of the indicators see Friant et al., 2008

${ }^{8}$ Equity function, Directive function and market regulation function (Ross \& Levacic, 1999, pp. 29$30)$.
} 


\subsection{What is the theoretical basis for the use of the incentive function of financing} formulas?

From a conceptual point of view, the arguments in favour of implementing such a procedure come from the rational choice theory. According to Rule (quoted by

Meadwell, 2002; Smith, 2002), "human action is essentially instrumental" (Meadwell, 2002, p.118) and the actors are looking for, rationally, lines of action that emphasise the "maximisation of the usefulness of the actor" (Haine, 1999). Consequently, the decisions of the actors are made taking into account and comparing the cost and profit factors. This theory is anchored on the postulates that "information is presumed perfect, all of the options are known and measured, the preferences defined, set, transitive and complete" (Haine, 1999). The actor needs to know and rank his options. He also needs to know how to reach his goal and have the material means to actually attain it. Conversely, the main barriers to implementing rational choices can be summarised as follows: impossibility to choose between two equal options, lack of information allowing the actor to compare different options available in full knowledge of the considerations involved and persistence of beliefs and uncertainties pertaining to the expected outcomes of the action (Gazibo \& Jenson, 2004). According to these principles, the different categories of actors can be guided by specific interests: "For example, if they are people buying and selling, maximizing wealth seems a reasonable assumption. If they are peasants in risky environments, maximizing security has some appeal. In the case of government actors, the presumption is that they want to stay in power." (Levi, 1997, p.24).

It is difficult to apply models of neoclassical economy as is to the study of school quasi-markets, as Felouzis and Perroton (2007) have demonstrated. They propose an analysis in terms of economics of quality. However, we make the following hypothesis when transposing the rational choice theory to the context of a 
highly hierarchical school quasi-market: if we accept that any school, personified by its head, tries to maximise its teaching staff, we can assume that rational choices will be made in order to attain this goal. The means that the school head can use to this end will depend upon the implementation of a policy of social mixing among schoolchildren in order to obtain optimal financing from the public authorities if the compensatory mechanisms are sufficient with respect to the supposed difficulty that this social mixing may engender. Accordingly, the dissemination of information related to financing measures must be guaranteed at least for schools.

However, the maximisation of the teaching staff does not apply to every actor. In the workings of the French-speaking Belgian school quasi-market, the maximisation of the "quality" of the public recruited also plays an important role (second-order competition). In a context of weak differentiation in teaching workforce, schools do not get any "profit" in having an underprivileged public, except in the case of positive discrimination schools. Because it is easier, for school workforces of the same size, to educate a certain type of public, institutions in a high position in the local school hierarchy (Delvaux \& Joseph, 2003) select pupils with a privileged background. This is true although until now there has been no monitoring of the quality effectively produced by each institution, contrary to the English system ${ }^{9}$. In this sense, the use of a formula that weights school staff funding according to the social status of pupils could make it possible to favour the recruiting of underprivileged pupils, as long as the supplementary means are considered sufficient and the supposed results (because they are not measured effectively via national

\footnotetext{
${ }^{9}$ Eurybase (2007/08). The Education System in England, Wales, Northern Ireland. Retrieved October 20, 2009, from: http://eacea.ec.europa.eu/education/eurydice/documents/eurybaseleurybase_full_reports/UN_ EN.pdf
} 
Educational Research and Evaluation

11

examinations, for example) remain acceptable in terms of client expectations - parents who wish to entrust their children to institutions that take the risk of modifying their recruitment policy. 


\section{Method}

\subsection{Corpus of data}

In order to build the indicators necessary for modulating the financing formula, we needed to work with reliable data on all of the schools in the French Community of Belgium, all levels combined (nursery, primary and secondary school). Because of the type and quantity of data required, we decided to work with data from the school population census used in the allocation of school funds, provided by the educational $\operatorname{administration}^{10}$.

Three data tables were used, each one corresponding to one census year of students in the French Community of Belgium: school years 2003-2004, 2004-2005 and 2005-2006. Each of these data tables contains as many records ${ }^{11}$ as students counted in the French Community of Belgium (approximately 860,000 per year), as well as the variables used in calculating the budget allocated to each institution and in constituting the general statistics for education (such as the school attended, the study level and track, the birthdate, the home country and municipality, the certificates earned and a socio-economic index score).

\footnotetext{
${ }^{10}$ In particular, the "Entreprise des Technologies Nouvelles de l'Information et de la Communication" (ETNIC)

${ }^{11}$ The records were made anonymous by the administration, which only retained a random identification number assigned to each student to allow mergers over several years.
} 
An important variable for our research is the socio-economic status of the students. It is represented by a socio-economic index ${ }^{12}$ (in the rest of this document, we will use the abbreviation "SES") present in the data tables and initially built to implement the policy of positive discrimination (Demeuse et al., 1999; Demeuse and Monseur, 1999).

\subsection{Construction of indicators at the level of the institution}

These data tables on the "student" level were aggregated at the level of schools, such that one record corresponds to one institution, and merged in order to establish an evolution over three consecutive years, including annual student flow (Demeuse and Delvaux, 2004).

Once the tables were aggregated at the level of the institution, different indicators were created related to the institutions. On the one hand they reflect the structure of the population of the institutions, and on the other hand the population flow to and from each of the institutions (Friant et al., 2008). Here we will focus only on the "average SES of the institution" variable.

\subsection{Development of a tool to simulate financing of institutions ${ }^{13}$}

The historical and educational context of the French Community of Belgium limits the means of action that the political authorities have, particularly in terms of

\footnotetext{
${ }^{12}$ The socio-economic index is based on the student's district of origin (the notion of district is a statistical division of the territory (Demeuse, 2002, p. 219). A synthetic socio-economic index score is assigned to each district in Belgium, on the basis of 11 variables within the framework of 6 domains (income per inhabitant, level of the certificates, unemployment rate, employment rate and proportion of people receiving welfare, professions, comfort of housing). Thus each student is assigned the socio-economic index score of the district where he lives and somehow brings this index score to the level of the institution. From a statistical point of view, this is a normal distribution metric variable that varies between -3.5 and 3.5. It is recalculated every three years on the basis of the latest statistics available.

${ }^{13}$ The simulation tool was made by Simon Uyttendaele, University of Liège.
} 
regulating the school quasi-market. The solution proposed in our research is to use economic leveraging, in this case through a change in the logic of financing schools.

To allow the political authorities to identify the impact of their decisions, it was necessary to provide the proper equipment: a computer tool was developed to estimate the impact of each decision on the institutions and on the overall budget for education. This simulator therefore makes it possible to evaluate the impact (on the level of the entire educational system as well as at the level of each of the primary and secondary schools) of a change in the rules for calculating the teaching staff.

To set up this simulator, it was first necessary to make a comparison between an existing situation (that can be considered the baseline) and a virtual situation that could exist later. Part of the development of the simulator depended on modelling the calculation of the number of teachers that a school can hire according to the rules currently in force. The software programme must be as flexible as possible and allow the parametering of financing scenarios according to pertinent criteria, such as the average socio-economic status of schools, the degree of grade repetition that is accepted or maintained in the school, the evolution of the school population with time or according to the school level considered... To this end, indicators of the social composition of the institutions and of their structure were calculated. But it is also necessary to establish a model that links financing to these characteristics: on the one hand, the idea is to propose a tool that breaks with the dichotomised financing used in the case of positive discrimination and, on the other hand, to propose a function that can either be increasing (for example, in the theoretical case of weighting of financing depending on results) or decreasing (for example, in the case of weighting of financing depending on the SES) (figure 1). 

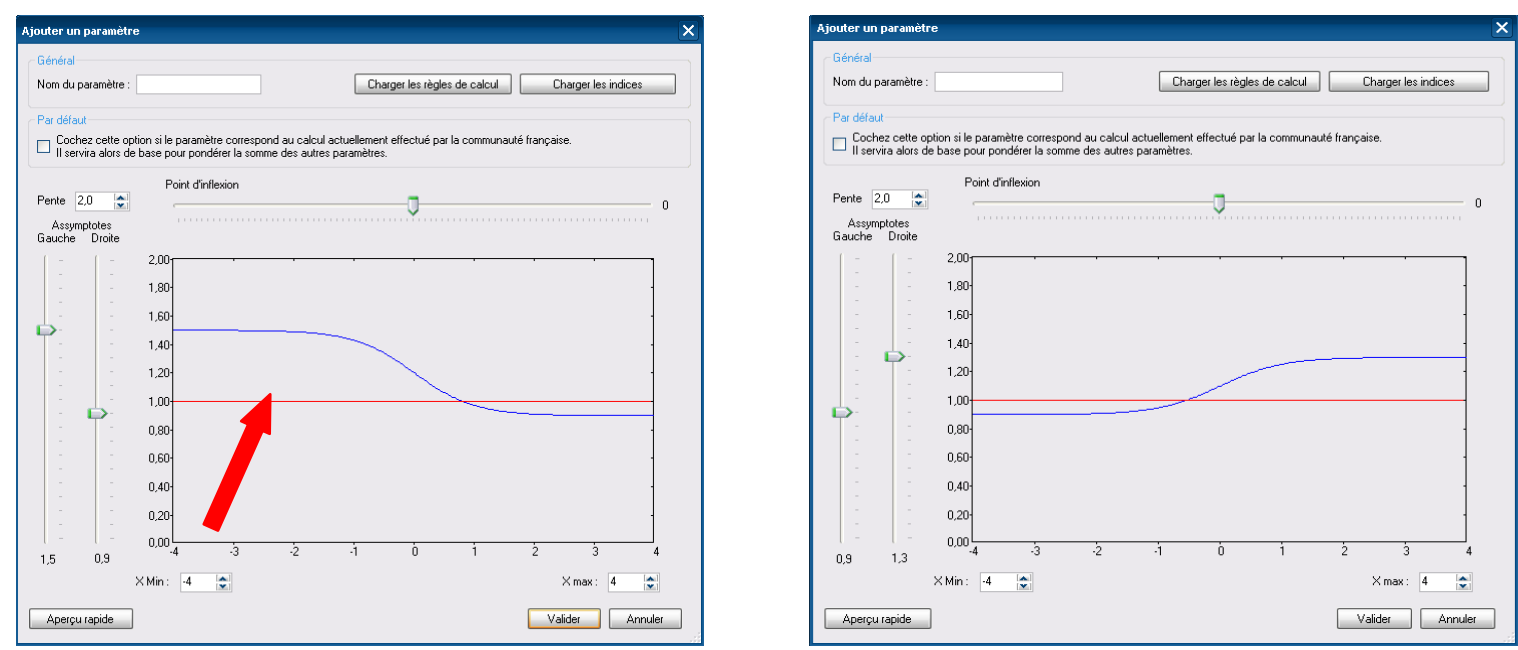

Figure 1 - The parametering window of the simulation tool: example of a decreasing curve (left) and of an increasing curve (right)

The logistical function ${ }^{14}$ (figure 1 presents two possible illustrations) makes it possible to:

- $\quad$ vary the minimum and maximum values of the weighting (y-axis);

- $\quad$ vary the minimum and maximum values of the weighting indices (x-axis);

- $\quad$ authorise increasing or decreasing functions;

- $\quad$ modulate the slope of the function;

- $\quad$ vary the moment where the increase/decrease begins and ends, that is, vary the point of inflexion of the mathematical function.

The use of this function allows great flexibility.

\subsection{Simulation procedure}

The simulations on school financing were performed on real data from all of the primary schools in the French Community of Belgium. A special effort was made to account for a maximum number of parameters to lead to realistic simulations. Two financing scenarios were simulated. The baseline was parametered using the budget,

\footnotetext{
${ }^{14}$ The logistical function is mathematically written as follows: $f(x)=a_{g}+\frac{\left(a_{d}-a_{g}\right)}{1+e^{(-a(x-\text { inf }))}}$

$a_{g}$ being the left asymptote, $a_{d}$ being the right asymptote, $a$ being the slope, and inf being the point of inflexion
} 
the number of pupils per school and the calculation procedures in force for school year 2005-2006. The budget considered concerns only the number of teachers and equates to 4.5 billion euros, plus an additional budget awarded to certain underprivileged schools in the framework of priority education, equivalent to $0.45 \%$ of the total budget (approximately 22 million euros).

This baseline, indicated by an arrow in figure 1, also appears in table 1: the formula does not modify the default parameters. Given that one pupil is equal to one pupil, both left and right asymptotes are set at 1 ; the slope is 0 , and there is no point of inflexion. This baseline is the point of comparison for the further scenarios.

Table 1 - Parameters related to the baseline

\begin{tabular}{|l|l|l|l|l|l|}
\hline & Left asymptote & $\begin{array}{l}\text { Right } \\
\text { asymptote }\end{array}$ & Slope & $\begin{array}{l}\text { Point of } \\
\text { inflexion }\end{array}$ & Budget \\
\hline Baseline & $\begin{array}{l}\mathbf{1} \\
\text { 1 pupil = 1 } \\
\text { pupil, no matter } \\
\text { the SES }\end{array}$ & $\begin{array}{l}\mathbf{1} \text { 1 pupil = 1 } \\
\text { pupil, no matter } \\
\text { the SES }\end{array}$ & $\begin{array}{l}\mathbf{0} \text { No differentiation in } \\
\text { financing, so no } \\
\text { slope }\end{array}$ & $\begin{array}{l}\text { - No point of } \\
\text { inflexion }\end{array}$ & $\begin{array}{l}\mathbf{1 0 0 \%} \text { Unchanged } \\
\text { budget }\end{array}$ \\
\hline
\end{tabular}

Starting with this baseline, two financing scenarios (the logic used, the configuration of the software programme and the effects of these scenarios) are presented in the following section.

To illustrate the effects the simulation scenarios could have, we have selected the case of two contrasting primary schools: one is underprivileged (school A), the other is slightly above average (school B). The distribution of the socio-economic index scores between schools is presented in figure 2. 


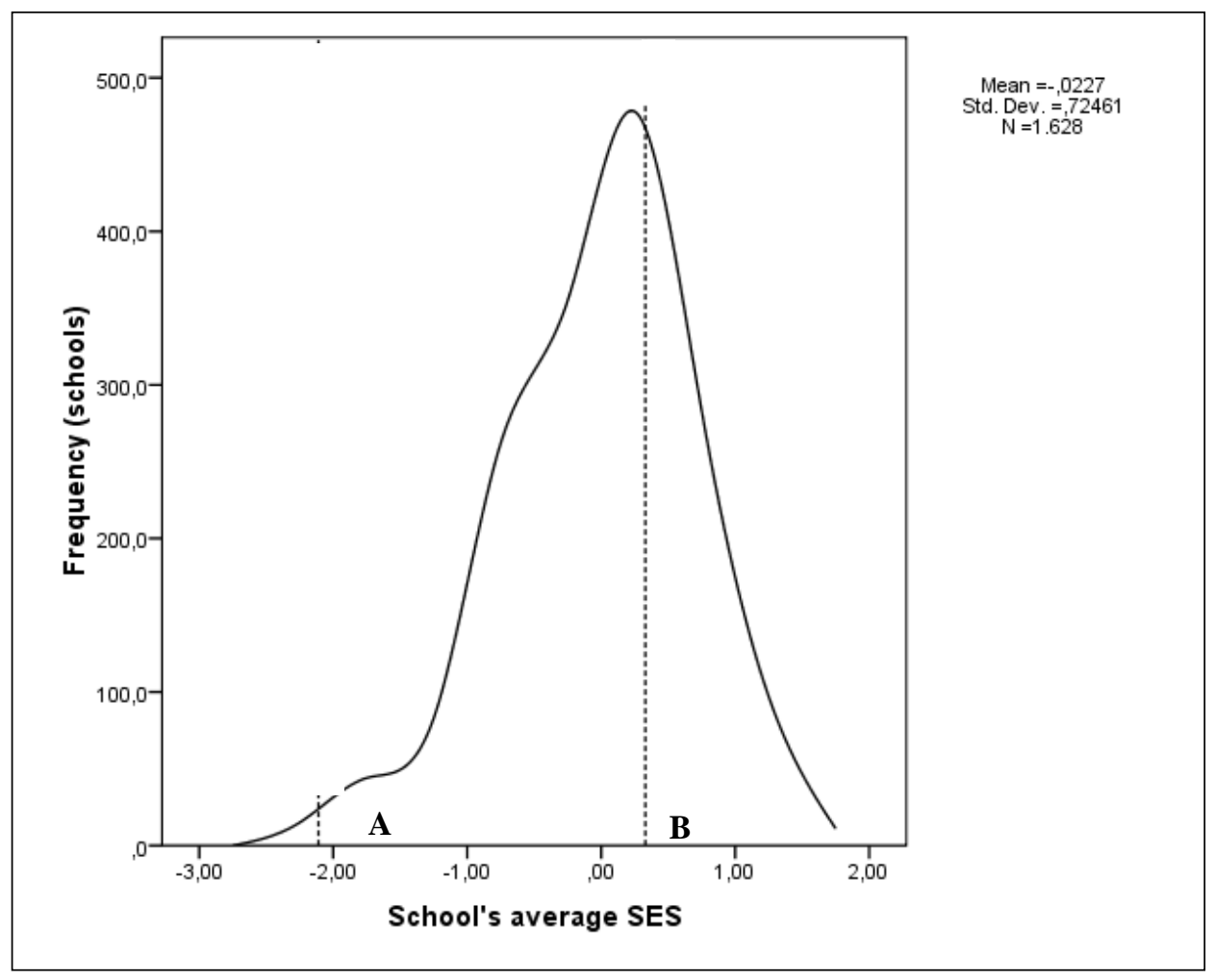

Figure 2 - Distribution of SES by school (2005), with the positions of the two schools studied

\section{Results}

\subsection{Two financing scenarios applied to two contrasting schools}

\subsubsection{The incentive scenario based on redistribution: "Robin Hood"}

The first scenario takes into account the indicator related to the social composition $(\mathrm{SES})^{15}$ of the school. We call it "Robin Hood" because it penalises schools whose pupils are on average privileged and that have little socio-economic mixing and gives more to the schools that are the most underprivileged, according to the following parametering (table 2 and figure 3 ).

\footnotetext{
${ }^{15}$ As a reminder, a negative value indicates that the pupils of the school are generally underprivileged. On the other hand, a positive value corresponds to the situation of a school whose pupils are mainly privileged.
} 
Table 2 - Parameters related to the "Robin Hood" scenario

\begin{tabular}{|c|c|c|c|c|c|}
\hline & Left asymptote & Right asymptote & Slope & $\begin{array}{l}\text { Point of } \\
\text { inflexion }\end{array}$ & Budget \\
\hline Baseline & 1 & 1 & 0 & - & $100 \%$ \\
\hline $\begin{array}{l}\text { "Robin } \\
\text { Hood" } \\
\text { scenario }\end{array}$ & $\begin{array}{l}\mathbf{1 . 6} \\
\text { a pupil from a } \\
\text { highly } \\
\text { underprivileged } \\
\text { background is } \\
\text { subsidised as } \\
1.6 \text { pupils }\end{array}$ & $\begin{array}{l}\mathbf{0 . 8} \\
\text { a pupil from a highly } \\
\text { privileged } \\
\text { background is } \\
\text { subsidised as } 0.8 \\
\text { pupils }\end{array}$ & $\begin{array}{l}\mathbf{2} \\
\text { Rapid } \\
\text { change of } \\
\text { weighting }\end{array}$ & $\begin{array}{l}\mathbf{0} \\
\text { The change in } \\
\text { weighting } \\
\text { occurs around } \\
\text { SES }=0\end{array}$ & $\begin{array}{l}\mathbf{1 0 0 \%} \\
\text { Unchanged } \\
\text { budget }\end{array}$ \\
\hline
\end{tabular}

A

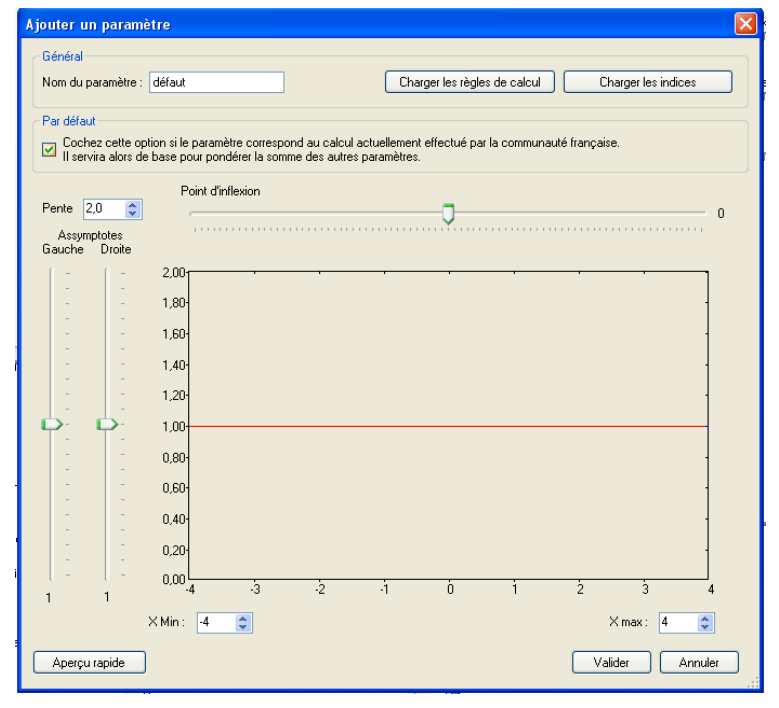

Figure 2 - simulation of the "baseline"

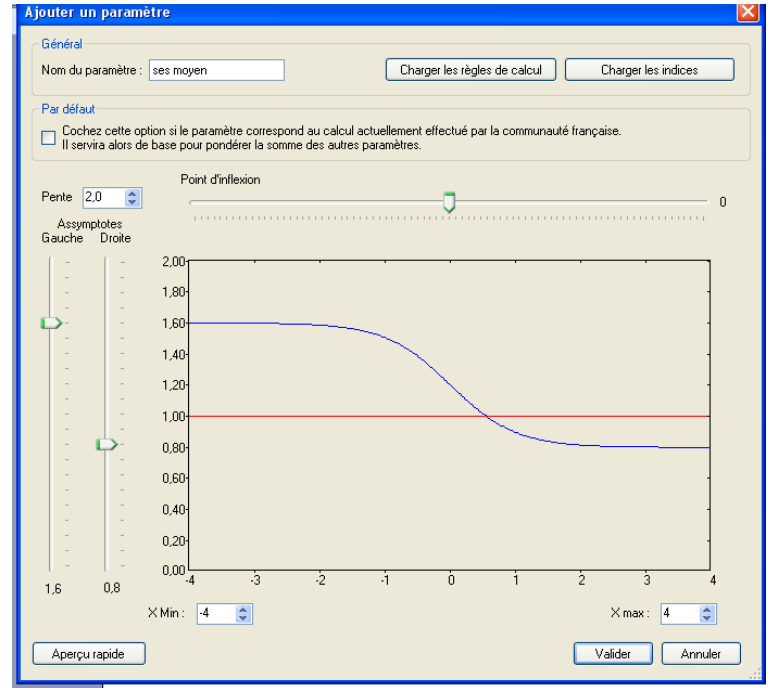

Figure 3 - "Robin Hood" simulation scenario

In the case of this simulation scenario ${ }^{16}$, schools with a population that is socio-economically underprivileged receive more funding whereas schools with a privileged, or very privileged, population are penalised with financing per pupil under the level of 1 . In this hypothetical case, the financing logic that was used combines a compensatory-type financing ("give the most to those who need it the most") with an incentive-type financing in the case of homogenous schools whose pupils are mainly socio-economically privileged (penalisation in terms of financing).

\footnotetext{
${ }^{16}$ This simulation is made without increasing the overall budget awarded by the department of education for financing schools.
} 
Educational Research and Evaluation

19

Table 3 - effects of the "Robin Hood" scenario

\begin{tabular}{|l|l|l|l|l|l|l|}
\hline \multicolumn{2}{|l|}{} & Baseline & \multicolumn{2}{l|}{ After the "Robin Hood" scenario } \\
\hline School & SES & $\begin{array}{l}\text { volume of } \\
\text { teaching hours }\end{array}$ & $\begin{array}{l}\text { Number of } \\
\text { full-time } \\
\text { teachers }\end{array}$ & $\begin{array}{l}\text { volume of } \\
\text { teaching } \\
\text { hours }\end{array}$ & $\begin{array}{l}\text { Gain in } \\
\text { full-time } \\
\text { teachers }\end{array}$ & $\begin{array}{l}\text { Gain in } \\
\text { teachers } \\
\text { (relative) }\end{array}$ \\
\hline A & 0.33 & 482 & 21.9 & 440 & -1.8 & $-8.71 \%$ \\
\hline B & -2.11 & 194 & 8.8 & 253 & +2.5 & $+30.41 \%$ \\
\hline
\end{tabular}

This table has 7 columns. The first column identifies the school ${ }^{17}$ whereas the

second provides the socio-economic index score of the school. The following two

columns concern the situation of the school before applying the "Robin Hood"

scenario: the total number of teaching hours and the significance of this value in terms

of numbers of full-time teachers that could be hired in this school. The next three

columns are related to the situation in the school after applying the "Robin Hood"

scenario: the number of teaching hours the school would receive after applying the

scenario, the gross profits in terms of equivalent full time according to the scenario

and finally the relative gains of the school - the division of the gross profits by the

number of teachers before the application of the scenario.

Reading table 3, it appears that the impact of the "Robin Hood" scenario is very different depending on the slot occupied by each of the schools in terms of average socio-economic index. School A is just above average ( $\mathrm{SES}=0.33$ ) while school B is very underprivileged ( $\mathrm{SES}=-2.11)$. In the case of school A, the consequences of financing scenario 1 take the form of a reduced teaching staff, -1.8 equivalent full time teachers, whereas in school B, the consequences of financing take the form of a better than $30 \%$ increase in teaching staff: the number of teachers rises from 8.8 to 11.3 .

\footnotetext{
${ }^{17}$ This was made impossible in order to respect the anonymity of the schools.
} 


\subsubsection{A compensatory scenario that adds new funding}

Although it is difficult to defend politically, the example of the "Robin Hood" scenario was chosen in this article because it truly implements an incentive for social mixing. More acceptable politically - taking into account the availability of supplementary funds - and faced with the contestation of laws that took on social mixing head on, the second simulation attempts to propose an undoubtedly more acceptable distribution of funds. In this second scenario, the will is to award more funds to schools with an underprivileged population, without sanctioning schools that educate a socio-economically privileged population, thanks to an overall increase in the budget (in comparison with the previous scenario, only the compensatory logic is retained here). We will call this the "compensatory scenario" in the rest of this article. Table 4 presents the parameters considered (presented in comparison with those retained in the "Robin Hood" scenario).

Table 4 - Parameters related to the compensatory scenario

\begin{tabular}{|l|l|l|l|l|l|}
\hline & $\begin{array}{l}\text { Left } \\
\text { asymptote }\end{array}$ & $\begin{array}{l}\text { Right } \\
\text { asymptote }\end{array}$ & Slope & $\begin{array}{l}\text { Point of } \\
\text { inflexion }\end{array}$ & Budget \\
\hline Baseline & 1 & 1 & 0 & - & $100 \%$ \\
\hline $\begin{array}{l}\text { "Robin Hood" } \\
\text { scenario }\end{array}$ & 1.6 & 0.8 & 2 & 0 & $100 \%$ \\
\hline $\begin{array}{l}\text { Compensatory } \\
\text { scenario }\end{array}$ & $\begin{array}{l}\mathbf{1 . 4} \\
\text { a pupil from a } \\
\text { highly } \\
\text { underprivileged } \\
\text { background is } \\
\text { financed as 1.4 } \\
\text { pupils }\end{array}$ & $\begin{array}{l}\mathbf{1} \text { the financing } \\
\text { does not } \\
\text { change for } \\
\text { the most } \\
\text { privileged } \\
\text { pupils }\end{array}$ & $\begin{array}{l}\mathbf{0 . 5} \\
\text { slow } \\
\text { change in } \\
\text { weighting }\end{array}$ & $\begin{array}{l}\text { the change } \\
\text { in } \\
\text { weighting } \\
\text { occurs } \\
\text { around } \\
\text { SES=-2 }\end{array}$ & $\begin{array}{l}\mathbf{- 2} \text { the total budget } \\
\text { is increased by } \\
\text { (approximately } \\
\text { €40 M) }\end{array}$ \\
\hline
\end{tabular}




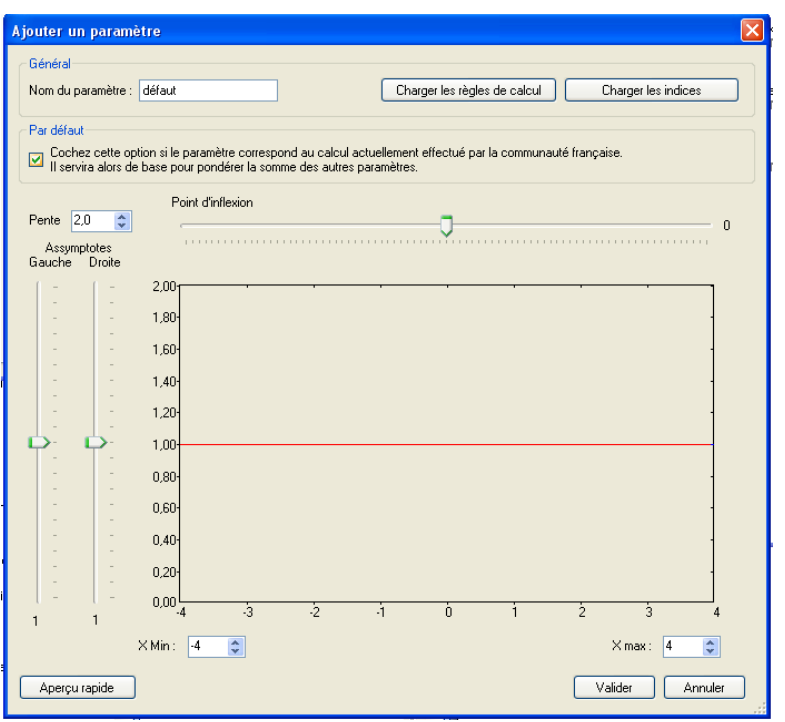

Figure 4: simulation of the "baseline"

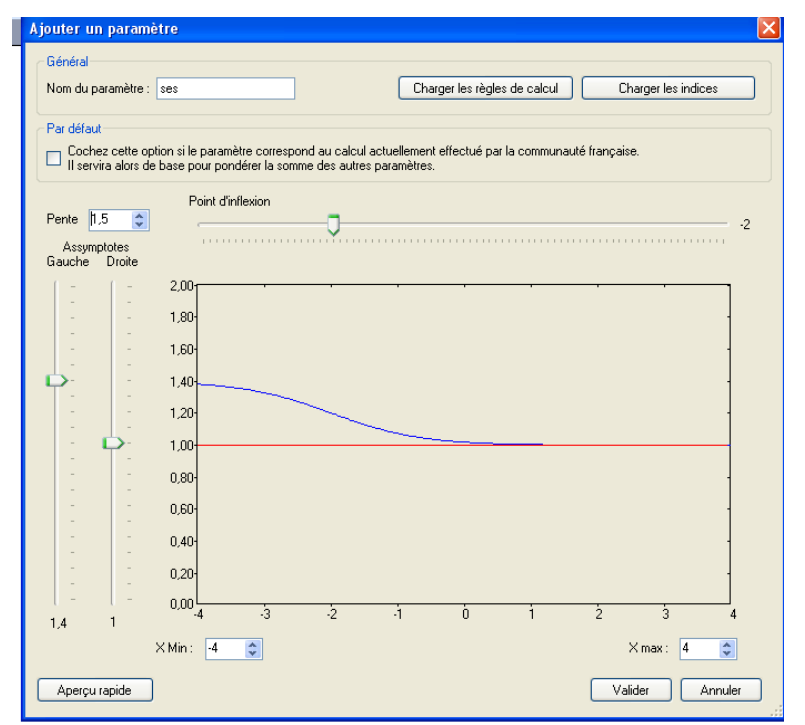

Figure 5: scenario of simulation 2

This measure was reproduced in the following way (figure 5): increase in the budget $^{18}$, parametering of the left asymptote at 1.40 (which means that a very underprivileged pupil will be financed as 1.4 pupils), the right asymptote at 1 . The association of a slope of 0.5 to a point of inflexion parametered at 0.2 makes it possible to define the rapidity of the change in weighting as well as the beginning and the end of the change in weighting; in this case, the intention was to reproduce the political priorities, i.e. to concentrate the financial effort ${ }^{19}$ on schools with the most underprivileged population [the curve representing the distribution of financing meets the baseline around the value -0.8 , which means that a pupil with a socio-economic index score higher than this value (de -0.8) does not have any positive financial weighting]. We see that applying this principle would make it possible, on one hand, for a large number of schools (located on the left of the x-axis) to increase teaching staff and, on another hand, for the rest of the schools (the ones on the right of the same axis) to not be restricted in terms of the level of hiring of teaching staff.

\footnotetext{
${ }^{18}$ As a reminder, the first simulation was made without a budget modification. In the case of financing scenario 2 , the budget was increased by $1 \%$.

${ }^{19}$ The distribution of financing can be seen in figure 5 (see arrow) by taking into account the space between the curve and the horizontal line.
} 
Concretely, the effects of applying this scenario can be investigated on the "school" level. Schools A and B, presented in the "Robin Hood" scenario, are represented in table 5. The comments related to this table are made further in the section comparing the compensatory scenario to the solution proposed by the Government.

Table 5 - effects of the compensatory scenario

\begin{tabular}{|l|l|l|l|l|l|l|}
\hline \multicolumn{2}{|l|}{} & \multicolumn{2}{|l|}{ Baseline } & \multicolumn{2}{l|}{$\begin{array}{l}\text { After simulation scenario 2 (continuous } \\
\text { distribution version) }\end{array}$} \\
\hline School & SES & $\begin{array}{l}\text { volume of } \\
\text { teaching hours }\end{array}$ & $\begin{array}{l}\text { Number of } \\
\text { full-time } \\
\text { teachers }\end{array}$ & $\begin{array}{l}\text { volume of } \\
\text { teaching hours } \\
\text { (simulation 1) }\end{array}$ & $\begin{array}{l}\text { Gain in full- } \\
\text { time teachers }\end{array}$ & $\begin{array}{l}\text { Gain in } \\
\text { teachers } \\
\text { (relative) }\end{array}$ \\
\hline A & 0.33 & 482 & 21.9 & 483 & +0 & $+0.21 \%$ \\
\hline B & -2.11 & 194 & 8.8 & 234 & +1.7 & $+20.62 \%$ \\
\hline
\end{tabular}

\subsection{The solution proposed by the Government}

The financing measures implemented in the French Community of Belgium at the beginning of the 2009 school year were modelled after a bill proposed by the Government. They are characterised by an increase in the budget (from $€ 22$ million $0.45 \%$ of the total budget - it goes to $€ 62$ million - $1.35 \%$ of the total budget - for all levels of education) and a desire to concentrate supplementary funds in schools with an underprivileged population. The distribution of these funds is illustrated in figure 6 drawn from a Government press release.

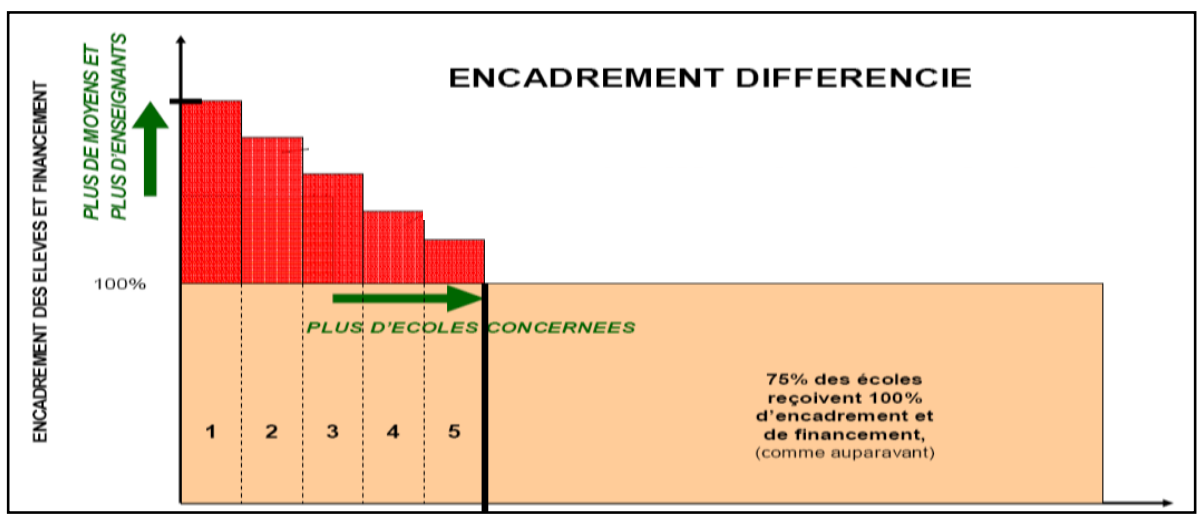

Figure 6 - illustration of the school workforce and financing according to the Government of the French Community (French Community, 2009) 
Educational Research and Evaluation

23

The choice of the French Community - to prefer financing by stages rather than according to a continuous distribution as in our simulations - is based on at least three reasons: the first has to do with the desire to simplify the calculation procedure, the second (a consequence of the first) has to do with the communication between the Government of the Community and its users (a parallel can be drawn between this logic and that of the rules of fiscal taxation), the third has to do with a desire to maximise the impact of the different financing measures (the effect produced by passing from one financing bracket to another is much more perceptible for a school than a small improvement in the situation allowed by a movement on the distribution curve).

Table 6 shows the effect of applying the solution proposed by the Government on the level of schools A and B (the same institutions already analysed in the case of the two previous situations).

Table 6 - effects of the solution proposed by the Government

\begin{tabular}{|l|l|l|l|l|l|l|}
\hline \multicolumn{3}{|c|}{} & \multicolumn{3}{|l|}{ Baseline } & \multicolumn{2}{|l|}{ After applying the Government's solution } \\
\hline School & SES & $\begin{array}{l}\text { volume of } \\
\text { teaching } \\
\text { hours }\end{array}$ & $\begin{array}{l}\text { Number of } \\
\text { full-time } \\
\text { teachers }\end{array}$ & $\begin{array}{l}\text { volume of } \\
\text { teaching hours }\end{array}$ & $\begin{array}{l}\text { Gain in full- } \\
\text { time teachers }\end{array}$ & $\begin{array}{l}\text { Gain in } \\
\text { teachers } \\
\text { (relative) }\end{array}$ \\
\hline A & 0.33 & 482 & 21.9 & 482 & 0 & 0 \\
\hline B & -2.11 & 194 & 8.8 & 251 & +2.4 & $+29.72 \%$ \\
\hline
\end{tabular}

\subsection{Comparison of the scenarios and the solution proposed by the Government} If we take a "micro" point of view for schools A and B, we see similarities between the two versions proposed: the school with a socially underprivileged population (school B) is favoured, in terms of school workforce, as the number of teaching hours awarded after the simulations is superior to the base number of teaching hours; on the other hand, as for school A, with a more privileged population, the teaching workforce remains unchanged between the initial situation and after the simulation. 
As for school B, it is interesting to note that the benefit recorded after the simulation is not of the same order depending on whether the distribution is continuous ("realistic" simulation) or discrete (the Government's bill): even if the gains recorded are close, the effects of financing by steps are more favourable for school B than financing through continuous distribution. It appears clear that this is the case of a school whose socio-economic index score corresponds to a benchmark establishing a division between two steps, which brought this school a maximisation of the financing allotted.

\section{Conclusion}

The simulations proposed in this article are based on the principle that the educational and pedagogical needs of a child depend on his social and cultural origin. They are intended to show the feasibility of a weighting of financing awarded to primary schools according to socio-economic indicators. The "Robin Hood" scenario is based on the principle of compensation, but adds an effect of incentive redistribution. The compensatory scenario, on the other hand, is based only on the principle of compensation, like the solution proposed by the Government. The "ideal" values to attribute to the different parameters of the simulator are not discussed here and are difficult to establish scientifically, in particular because the use of means by the organising authorities ${ }^{20}$ remains in the domain of the freedom of methods and because the organising authorities do not have to, as is the case in other systems, demonstrate the relative efficiency of their choices, taking into account the populations schooled.

These simulations indicate that weighting financing according to socioeconomic parameters is possible and easily adaptable depending on clearly defined

\footnotetext{
${ }^{20}$ The organising authority of an educational institution is the authority, the natural person(s) or corporate body or bodies that are responsible for it. (law of 29 May 1959, called the "Pacte scolaire")
} 
Educational Research and Evaluation

25

priorities. However, some characteristics of the financing of primary education may neutralise part of the effects of the introduced weighting. It is a question here, for example, of the existence of minimum funding such as that foreseen by the

Government to avoid having part-time positions with only a few hours: teaching designations would be made at the level of individual locations rather than at the institutional level, which can group together several school locations.

The simulator also makes it possible to create financing scenarios based on several indicators. However, combining several indicators requires the utmost prudence in particular if there is a relationship between the different indicators used (for example: socio-economic index score and rate of grade repetition). Also, any financing scenario must include a reflection on the strategies that certain school heads could develop to maximise their teaching workforce. As an example, if the political powers decide to increase the teaching staff in schools that have little grade repetition, headmasters could guide their pupils in difficulty towards special education or vocational education without penalising them with a failure. On the other hand, additional funding for schools with a high rate of grade repetition could incite headmasters to increase the number of failing students.

We would like to insist on an important aspect of the study that led to this article: a single angle of investigation, the financial aspect, is not a miracle solution to all the difficulties encountered by the educational system in French-speaking Belgium. Greater funding can certainly help level out chances to succeed, but how should this extra funding be used? Continuing to do the same thing, considering for example that this supplement allotted to some schools exempts socially privileged schools from increasing social mixing, does not square with the principles promoted 
by the "Contrat pour l'Ecole". The idea of raising resource allocation for the most underprivileged schools while transferring funding from the schools that refuse to increase social mixing (the "Robin Hood" effect) could be a strong signal but certainly difficult to support from a political point of view.

The implementation of differentiated funding measures cannot overlook a reflection on how to evaluate these measures. Indicators making it possible to evaluate the possible social mixing resulting from these new measures should be built at the micro level, i.e. at the level of each school (average socio-economic index score, evolution of this score, standard deviation of the score, etc...) and/or at the system level (Demeuse and Baye, 2007; 2008) in order to evaluate the attainment of the goals and, if necessary, to end these measures once the goal of social mixing is reached. 
Acknowledgements

The authors would like to thank the Government of the French Community of Belgium for giving them the opportunity to carry out this research. Their thanks also goes out to ETNIC for providing the statistics, to Christian Monseur, Simon Uyttendaele and Thomas Herreman from the University of Liège for their participation in the research, and to Ramona Shelby for translating the article from French to English.

References

Aubert-Lotarski, A., Demeuse, M., Derobertmasure, A., Friant, N. (2007). Conseiller le politique: des évaluations commanditées à la prospective en éducation. Les Dossiers des Sciences de l'Education, 18, 119-128.

Baye, A., Demonty, I., Fagnant, A., Lafontaine, D., Matoul, A., Monseur, C. (2004). Les compétences des jeunes de 15 ans en Communauté française de Belgique en mathématiques, en lecture et en sciences. Résultats de l'enquête PISA 2003. Les Cahiers du Service de Pédagogie Expérimentale, 19- 20.

Borman, G.D., Stringfield, S.C., Slavin, R.E. (eds.) (2001). Title I. Compensatory Education at the Crossroads. Mahawah (NJ): Lawrence Erlbaum Associates.

Boudon, R. (2002). Théorie du choix rationnel ou individualisme méthodologique? Sociologie et sociétés, 34 (1), 9-34.

French Community of Belgium (2002). Décret du 27 mars 2002 modifiant le décret du 30 juin 1998 visant à assurer à tous les élèves des chances égales d'émancipation sociale, notamment par la mise en œuvre de discriminations positives et portant diverses mesures modificatives (Moniteur belge: 16 April 2002).

French Community of Belgium (2007). Décret du 8 mars 2007 “portant diverses mesures visant à réguler les inscriptions et les changements d'école dans l'enseignement obligatoire" (Moniteur belge: 03 July 2007)

French Community of Belgium (2008). Décret du 18 juillet 2008 "visant à réguler les inscriptions des élèves dans le ler degré de l'enseignement secondaire et à favoriser la mixité sociale au sein des établissements scolaires" (Moniteur belge: 26 August 2008)

Crahay, M. (2000). L'école peut-elle être juste et efficace? De l'égalité des chances à l'égalité des acquis. Brussels: De Boeck, Pédagogies en développement.

Delvaux, B. (2005). Ségrégation scolaire dans un contexte de libre choix et de ségrégation résidentielle. In M. Demeuse, A. Baye, M.H. Straeten, J. Nicaise, A. Matoul (Eds.), Vers une école juste et efficace. Vingt-six contributions à l'analyse des systèmes d'enseignement et de formation (pp.275-296). Brussels: De Boeck.

Delvaux, B. \& Joseph, M. (2003). Les espaces locaux d'interdépendance entre écoles. Louvain: Cerisis-UCL.

Delvaux, B., Demeuse, M., \& Dupriez, V. (2005). En guise de conclusion: encadrer la liberté. In M. Demeuse, A. Baye, M.H. Straeten, J. Nicaise, A. Matoul (Eds.), Vers une école juste et efficace. Vingt-six contributions à l'analyse des systèmes d'enseignement et de formation (pp. 559-574). Brussels: De Boeck.

Delvaux, B., Demeuse, M., Dupriez, V., Fagnant, A., Guisset, C., Lafontaine, D., Marissal, P. \& Maroy, C. (2005). Les bassins scolaires : de l'idée au projet. Propositions relatives aux domaines d'intervention, aux instances et aux territoires. Rapport de recherche (non publié).

Demeuse, M. (2002). Analyse critique des fondements de l'attribution des moyens destinés à la politique de discrimination positive en matière d'enseignement 
en Communauté française de Belgique. Liège: Université de Liège

(Dissertation doctorale en Sciences psychologiques).

Demeuse, M, \& Baye, A. (2008). Indicateurs d'équité éducative. Une analyse de la ségrégation académique et sociale dans les pays européens. Revue Française de Pédagogie, 165, 91-103.

Demeuse, M., \& Baye, A. (2007). Measuring and Comparing the Equity of Education Systems in Europe. In N.C. Soguel, \& P. Jaccard (Eds), Governance and Performance of Education Systems (pp. 85-106). Dordrecht: Springer.

Demeuse, M., \& Delvaux, B. (2004). Mobilité des élèves dans le système éducatif belge francophone. Relief, 4, 329-338.

Demeuse, M., Lafontaine, D., \& Straeten, M.-H. (2005). Parcours scolaire et inégalités de résultats. In M. Demeuse, A. Baye, M.H. Straeten, J. Nicaise, A. Matoul (Eds.), Vers une école juste et efficace. Vingt-six contributions à l'analyse des systèmes d'enseignement et de formation (259-274). Brussels: De Boeck.

Demeuse, M., \& Monseur, C. (1999). Analyse critique des indicateurs déterminant l'attribution des moyens destinés à la politique de discrimination positive en Communauté française de Belgique. Mesure et Evaluation en Education, 22(23), 97-127.

Demeuse, M., Derobertmasure, A., Friant, N., Herremans, T., Monseur, C., Uyttendaele, S., \& Verdale, N. (2007). Étude exploratoire sur la mise en ouvre de nouvelles mesures visant à lutter contre les phénomènes de ségrégation scolaire et d'inéquité au sein du système éducatif de la Communauté française de Belgique. Electronic document available from the website of the French Community of Belgium at the address: http://www.enseignement.be/download.php?do_id=5203\&do_check=

Dumay, X., (2004). Effet établissement: effet de processus et/ou effet de composition. Les cahiers de Recherche en Education et Formation, 36, 2-23.

Dupriez, V., \& Draelants, H. (2003). Classes homogènes versus classes hétérogènes: les apports de la recherche à l'analyse de la problématique. Les Cahiers de Recherche du GIRSEF, 24, 1-24.

Duru-Bellat, M., \& Mingat, A. (1997). La constitution de classes de niveau dans les collèges: Les effets pervers d'une pratique à visée égalisatrice. Revue Française de Sociologie, 38, 759-789.

Duru-Bellat, M. \& Meuret, D. (2001). Nouvelles formes dans les systèmes éducatifs étrangers: autonomie et choix des établissements scolaire. Revue Française de Pédagogie, 131, 173-221.

Eurybase (2007/08). The Education System in England, Wales, Northern Ireland. Retrieved October 20, 2009, from:

http://eacea.ec.europa.eu/education/eurydice/documents/eurybaseleurybase f ull_reports/UN_EN.pdf

Felouzis, G., \& Perroton, J. (2007). Les "marchés scolaires": une analyse en termes d'économie de la qualité. Revue Française de Sociologie, 48 (4), 693-722.

Friant, N., Derobertmasure, A., \& Demeuse, M. (2008). Les liens entre recherche prospective, description du système éducatif et pilotage: un exemple en Communauté française de Belgique. In L. Mottier Lopez, Y-E. Dizerens, G. Marcoux, \& A. Perréard Vité (Eds.), Entre la régulation des apprentissages et le pilotage des systèmes: évaluations en tension. Actes du 20e colloque de l'ADMEE-Europe, Université de Genève. Retrieved February 20, 2009, from: 
https://plone.unige.ch/sites/admee08/communications-individuelles/v-a4/v-a4$\underline{2}$

Friant, N., Demeuse, M., Aubert-Lotarski, A. \& Nicaise, I. (2008). Les politiques d'éducation prioritaire en Belgique: deux modes de régulation des effets d'une logique de marché. In M. Demeuse, D. Frandji, D. Greger, \& J-Y. Rochex (Eds.), Les politiques d'éducation prioritaire en Europe: Conceptions, mises en æeuvre, débats (pp. 87-132). Lyon: INRP.

Galand, B. (2007). Inscriptions scolaires et mixité sociale: beaucoup de bruit pour rien? Retrieved September 17, 2009, from:: http://www.changementegalite.be/IMG/pdf/tude_inscriptions_et_mixite.pdf

Gazibo, M., Jenson, J. (2004). La politique comparée: fondements, enjeux et approches théoriques. Montreal: Les Presses de l'Université de Montréal.

Government of the French Community of Belgium (2005). Contrat pour l'école: 10 priorités pour nos enfants. Electronic document available from the website "Contrat pour l'École":

http://www.contrateducation.be/contrat_presentation.asp (consulted February 2009).

Government of the French Community of Belgium (2009). Encadrement différencié. Plus d'enseignants et plus de moyens pour une école de l'excellence. Press release.

Haine, J.-Y. (1999). Rationalités et relations internationales. Cultures \& Conflits, 36. http://www.conflits.org/index310.html\#author (consulted February 2009)

Ireson, J., \& Hallam, S. (2001). Ability Grouping in Education. London: Paul Chapman Publishing.

Levi, M. (1997). A model, a method, and a map: Rational choice in comparative and historical analysis. In M. Irving Lichbach, \& A.S. Zuckerman (Eds), Comparative politics: Rationality, culture, and structure (pp. 19-41). Cambridge: Cambridge University Press

Maroy, C. \& Dupriez, V. (2000). La régulation dans les systèmes scolaires. Proposition théorique et analyse du cadre structurel en Belgique francophone. Revue Française de Pédagogie, 130, 73-87.

Maroy, C. (2006). Ecole, régulation et marché - une comparaison de six espaces scolaires locaux en Europe. Paris: Presses Universitaires de France.

Meadwell, H. (2002). La théorie du choix rationnel et ses critiques. Sociologie et sociétés, 34(1), 117-124.

Mons, N. (2007). Les nouvelles politiques éducatives. La France fait-elle les bons choix ?Paris : Presses universitaires de France, coll. "Education et société ».

Monseur, C., \& Crahay, M. (2008). Composition académique et sociale des établissements, efficacité et inégalités scolaires: une comparaison internationale. Revue Française de Pédagogie, 164, 55-65.

Ross, K. \& Levacic, R. (1999). Needs-based resource allocation in education. Paris: International Institute for Educational Planning.

Rule, J. (1988). Theories of Civil Violence. Berkeley: University of California Press.

Slavin, R.E. (1990). Achievement effect of ability grouping in secondary schools: A best-evidence synthesis. Review of Educational Research, 60 (3 , 471 - 499.

Smith, M.R. (2002). Les problèmes attribués à la théorie du choix rationnel. Sociologie et sociétés, 34 (1), 87-99.

Thrupp, M., Lauder, H., \& Robinson, T. (2002). School composition and peer effects. International Journal of Educational Research, 37(5), 483-504. 
Thrupp, M. (1999). Schools making a difference: let's be realistic! Open University Press.

Vandenberghe V. (1998). L'enseignement en Communauté française de Belgique: un quasi-marché. Reflets et perspectives de la vie économique, 37 (1), 65-75.

Vandenberghe V. (2001). Nouvelles formes de régulation dans l'enseignement: origines, rôle de l'évaluation et enjeux en termes d'équité et d'efficacité. Education et Société, 8 (2), 111-123. 